\title{
PESAN, KESADARAN, DAN PERILAKU HEMAT LISTRIK RUMAH TANGGA
}

\author{
Lilik Noor Yuliati $^{\left.{ }^{*}\right)}$, Irmayani Nurasrina ${ }^{1}$ \\ ${ }^{1}$ Departemen IImu Keluarga dan Konsumen, Fakultas Ekologi Manusia, Institut Pertanian Bogor, \\ Bogor 16680, Indonesia \\ *) E-mail: lilik_noor@yahoo.com.id
}

\begin{abstract}
Abstrak
Penelitian ini bertujuan untuk menganalisis hubungan antara pesan hemat listrik, kesadaran hemat listrik, dan perilaku hemat listrik pada rumah tangga di Taman Cimanggu, Kota Bogor. Contoh berjumlah 113 rumah tangga yang dipilih dengan metode stratified random sampling berdasarkan tingkatan daya listrik di rumah. Data dikumpulkan melalui wawancara. Data dianalisis secara deskriptif dan uji korelasi Spearman. Hasil penelitian menunjukkan bahwa contoh mempercayai televisi sebagai media dan pemerintah sebagai kelompok acuan dalam menyampaikan pesan hemat listrik. Contoh memiliki kesadaran dan perilaku hemat listrik dalam kategori sedang. Berdasarkan indikator pemanfaatan listrik primer dan sekunder, sebagian besar contoh telah dapat melakukan efektivitas penggunaan listrik. Analisis korelasi menunjukkan bahwa kesadaran berhubungan signifikan dengan pendidikan dan besar rumah tangga. Perilaku hemat listrik juga berhubungan signifikan dengan jumlah sumber pesan, jumlah pesan yang diingat, besar rumah tangga, pendapatan per kapita, daya, dan rekening listrik.
\end{abstract}

Kata kunci: hemat energi listrik, kesadaran, pemasaran sosial, pesan, rumah tangga

\section{Messages, Awareness, and Behavior Electricity Eficiency of Household}

\begin{abstract}
This study aims to analyze correlation between electricity-saving messages, awareness of electricity saving, and electricity saving behavior of households in Cimanggu Park, Bogor City. Contohts numbered 113 households selected by stratified random sampling method base on level of electricity power in the house. Data were collected through interviews. Data were analyzed descriptively and Spearman correlation test. The results showed that the contohts trust the television as the media and government as the reference group in powersaving message. Contohts have the awareness and electricity saving behavior in moderate category. Based on the indicators of primary and secondary power utilization, the majority of contohts have been able to make effective use of electricity. Correlation analysis showed that awareness associated significantly with education and household size. Electricity saving behavior was also associated significantly with the number of source messages, number of messages recalled, household size, income per capita, power, and electricity bills.
\end{abstract}

Keywords: awareness, electricity energy efficiency, household, message, social marketing

\section{PENDAHULUAN}

Setiap manusia membutuhkan listrik untuk menunjang aktivitas sehari-hari. Menurut Susanta dan Agustoni (2007), listrik di Indonesia yang dikelola oleh Perusahaan Listrik Negara atau PLN dihasilkan dari energi yang dapat diperbaharui (misalnya pembangkit listrik tenaga air atau PLTA) dan tidak dapat diperbaharui (misalnya PLTU dan PLTD). Menurut Adywibowo (2010), suplai listrik Indonesia 60 persen masih mengandalkan pembangkit listrik berbahan bakar minyak. Pembangkit listrik berbahan bakar minyak ratarata membutuhkan 3 liter solar untuk menghasilkan $1 \mathrm{kWh}$ listrik. Kondisi ini kian melebarkan selisih harga produksi dan tarif listrik.

PLN membutuhkan biaya untuk menjalankan proses pembangkitan dan penyaluran listrik. PLN membebankan biaya pembangkitan dan penyaluran listrik pada konsumen lewat mekanisme tarif dasar listrik (TDL). Menurut Bhaskoro (2010), untuk memproduksi $1 \mathrm{kWh}$ listrik, PLN memerlukan biaya rata-rata sebesar Rp1.700,00. Sementara itu, pemerintah mengharuskan PLN untuk menjual $1 \mathrm{kWh}$ listriknya seharga rata-rata Rp550. Pemerintah juga memberikan subsidi kepada PLN untuk menutupi kerugian tersebut. Pada tahun 2010 pemerintah memberikan subsidi listrik sebesar 37,8 triliun rupiah. 
Kerugian akan semakin meningkat karena pertambahan konsumsi listrik PLN tidak diimbangi dengan peningkatan kapasitas produksi listrik PLN. Kapasitas terpasang pembangkit listrik saat ini sebesar 29.705 MW. Hampir 67 persen dari total pelanggan yang menggunakan kapasitas tersebut berdomisili di Area Jawa dan Bali (Kuncoro, 2008). Persoalan lain yang sering muncul terkait dengan konsumsi energi pada sektor rumah tangga di antaranya adalah adanya disparitas (perbedaan) dalam konsumsi energi antara kelompok masyarakat miskin dengan kelompok yang kaya (Nuryanti \& Herdinie, 2007).

Salah satu upaya pemerintah untuk menghindari krisis listrik adalah dengan melakukan pemasaran sosial mengenai penghematan listrik yang memiliki bentuk konkret berupa pesan hemat listrik. Pesan hemat listrik tersebut disebarkan melalui media yang strategis dan disimak khalayak, misalnya televisi. Pesan hemat listrik yang pernah diterima rumah tangga contoh terdiri atas pesan versi artis Lidya Kandou, versi 17.00-22.00 WIB, dan versi maskot hemat listrik. WWF pun mengeluarkan pesan hemat listrik berupa ajakan mematikan lampu selama satu jam atau Earth Hour.

PLN dan pemerintah berkepentingan menyediakan listrik yang memadai bagi seluruh masyarakat Indonesia, juga memastikan subsidi jatuh pada tangan yang tepat. Pelanggan listrik berkepentingan untuk menerima pasokan listrik secara lancar. Turunnya tagihan listrik merupakan keuntungan nyata yang bisa langsung dirasakan masyarakat pengguna listrik rumah tangga. Alat listrik pun akan awet jika digunakan sesuai kapasitasnya.

Berdasarkan pemaparan tersebut, penelitian ini bertujuan untuk menganalisis pesan hemat listrik yang pernah diterima, tingkat kesadaran dalam menghemat listrik, dan perilaku hemat listrik dalam rumah tangga. Penelitian ini juga bertujuan untuk menganalisis hubungan antara pesan hemat listrik, kesadaran hemat listrik, dan perilaku hemat listrik pada rumah tangga.

\section{METODE}

Desain penelitian adalah cross sectional study. Penelitian bertempat di wilayah cakupan UPJ Bogor Kota di gardu dengan jumlah pelanggan terbanyak, yaitu gardu Kedung Waringin Komplek (KDK), tepatnya di Taman Cimanggu, Kelurahan Kedung Waringin,
Kecamatan Tanah Sareal, Kota Bogor. Pengambilan data dilakukan pada bulan Mei sampai dengan bulan Juni 2010.

Rumah tangga yang terlibat dalam penelitian ini (contoh) berjumlah 113 rumah tangga. Jumlah contoh dihitung menggunakan rumus Slovin dengan galat sebesar $10 \%$. Contoh dipilih menggunakan metode stratified random sampling. Contoh terdiri atas pengguna layanan listrik rumah tangga PLN golongan 900 VA (46 rumah tangga), 1300 VA (32 rumah tangga), 2200 VA (32 rumah tangga), dan $>2200$ VA (3 rumah tangga). Setiap rumah tangga contoh pada masing-masing golongan daya dihitung secara proporsional untuk menentukan jumlah rumah tangga contoh di tiap golongan.

Data yang digunakan adalah data primer dan sekunder. Metode pengumpulan data primer yang digunakan dalam penelitian ini adalah teknik wawancara dengan bantuan kuesioner. Data primer yang dikumpulkan adalah karakteristik rumah tangga contoh (umur, pendidikan, pengetahuan perilaku, daya, rekening listrik, pendapatan per kapita), pesan hemat listrik, kesadaran rumah tangga contoh, dan perilaku penggunaan listrik rumah tangga contoh. Data sekunder berupa golongan daya listrik terpasang diperoleh langsung lewat instansi terkait, yaitu Kantor Pelayanan PLN Bogor. Data rekening listrik rata-rata nasional setiap golongan diperoleh dari literatur yang memuat keputusan presiden mengenai tarif listrik.

Karakteristik rumah tangga contoh terdiri atas umur, pendidikan, pengetahuan perilaku, daya terpasang, besar rumah tangga, dan pendapatan per kapita. Berdasarkan pembagian umur Papalia dan Olds (2006), umur dikelompokkan menjadi enam kelompok umur, yaitu remaja (17-19 tahun), dewasa awal (20-30 tahun), dewasa madya (31-40 tahun), dewasa akhir (41-50 tahun), lansia awal (51-60 tahun), dan lansia akhir (> 60 tahun). Pendidikan dikelompokkan menjadi lima kelompok yaitu SD-SMP (pendidikan dasar), SMA, diploma (D1, D2, D3), sarjana (S1), dan pascasarjana (S2, S3). Pengetahuan perilaku terdiri atas delapan belas (18) indikator. Indikator-indikator yang mampu dijawab dengan tepat oleh rumah tangga contoh dinilai dalam persen dan dikategorikan menjadi rendah $(<60 \%)$, sedang $(60-80 \%)$, dan tinggi $(>80 \%)$. Daya terpasang rumah tangga contoh dikategorikan menurut kategori yang ditentukan PLN, yaitu 900 VA, 1300 VA, 2200 VA, dan 2200 VA. Besar rumah tangga rumah tangga 
contoh dikategorikan berdasarkan BKKBN (1998), yaitu keluarga kecil (> 4 orang), keluarga sedang (5-6 orang), dan keluarga besar (> 7 orang).

Pendapatan per kapita dikelompokkan menjadi enam kelompok berdasarkan sebaran pendapatan rumah tangga contoh. Kelompok pendapatan pertama adalah kurang dari Rp212.210.00, atau lebih kecil dari garis kemiskinan perkotaan Jawa Barat menurut BPS Provinsi Jawa Barat tahun 2010. Kelompok pendapatan per kapita selanjutnya adalah antara Rp212.210,00 sampai dengan Rp1.700.000,00. Nilai Rp1.700.000,00 adalah rata-rata pendapatan per kapita. Selanjutnya kelompok pendapatan per kapita ditentukan berdasarkan kelipatan Rp1.700.000,00 sampai dengan lebih besar daripada Rp6.800.000,00.

Pesan hemat listrik dalam penelitian ini mencakup sumber pesan yang dipercaya, sumber yang memberi banyak informasi, dan jumlah sumber pesan yang diakses. Sumber pesan dibedakan menjadi media dan kelompok acuan. Sumber pesan media terdiri atas televisi, radio, media cetak, media pendukung, internet, dan penyuluhan. Sedangkan kelompok acuan terdiri atas keluarga, teman, dan tetangga, artis, pemerintah, dan tokoh masyarakat. Rumah tangga contoh menyatakan berasal dari media apa saja atau dari kelompok acuan mana saja (boleh lebih dari satu) pesan hemat listrik diperoleh, serta dari media atau kelompok acuan mana saja (boleh lebih dari satu) pesan yang dipercaya rumah tangga contoh. Jumlah sumber pesan adalah jumlah sumber yang diakses rumah tangga contoh untuk memperoleh pesan hemat listrik (kemungkinan jumlah sumber adalah nihil sampai dengan sepuluh).

Kesadaran dalam penelitian ini diukur dengan beberapa indikator. Pada setiap indikator, rumah tangga contoh menyatakan dirinya belum sadar, netral, atau sadar sesuai dengan keadaan yang ada pada rumah tangga contoh. Secara keseluruhan, kesadaran rumah tangga contoh dikelompokkan menjadi rendah $(<60 \%)$, sedang $(60-80 \%)$, dan tinggi $(>80 \%)$.

Konfirmasi hemat listrik terdiri atas jumlah dan waktu penggunaan alat listrik, pemanfaatan primer dan sekunder, tagihan listrik, dan perilaku hemat listrik. Jumlah dan waktu penggunaan alat listrik dihitung dalam satuan buah per jam per hari, yaitu seberapa lama (dalam satuan jam) sebuah alat listrik digunakan dalam satu hari. Alat listrik yang tidak digunakan setiap hari akan dikonversikan ke dalam satuan yang sama (buah per jam per hari). Masing-masing pemanfaatan primer dan sekunder listrik dihitung secara keseluruhan (jumlah alat dikalikan dengan lama penggunaan dalam satuan jam). Pemanfaatan primer dan sekunder selanjutnya dibandingkan untuk melihat pola penggunaan listrik rumah tangga contoh, apakah rumah tangga contoh lebih banyak menggunakan alat listrik untuk pemanfaatan primer atau pemanfaatan sekunder. Rekening listrik rata-rata rumah tangga contoh merupakan rata-rata rekening listrik selama bulan Januari sampai dengan Maret 2010. Rekening listrik dibandingkan dengan rekening listrik rata-rata nasional untuk mengetahui bagaimanakah penggunaan listrik rumah tangga contoh (rekening listrik merupakan indikator penggunaan listrik) dibandingkan dengan rekening listrik rata-rata nasional. Sementara itu, perilaku hemat listrik terdiri atas delapan belas indikator. Masingmasing indikator dijawab rumah tangga contoh sesuai dengan keadaan yang ada, dengan pilihan jawaban tidak pernah, kadang, atau selalu. Secara keseluruhan, perilaku hemat listrik dikelompokkan menjadi rendah $(<60 \%)$, sedang $(60-80 \%)$, dan tinggi $(>80 \%)$.

Data yang telah dikumpulkan diolah dan dianalisis. Analisis data yang digunakan dalam penelitian ini adalah uji korelasi Spearman. Uji ini digunakan untuk menganalisis hubungan antara pesan hemat listrik, kesadaran hemat listrik, dan perilaku hemat listrik pada rumah tangga contoh.

\section{HASIL}

\section{Karakteristik Rumah Tangga}

Berdasarkan kategori usia Papalia dan Olds (2006), dua dari lima contoh tergolong dalam usia dewasa akhir. Proporsi terbesar contoh adalah berpendidikan sarjana $(36,3 \%)$ dan SMA $(31,9 \%)$. Berdasarkan pengetahuan perilaku hemat listrik, dua dari tiga contoh memiliki pengetahuan perilaku hemat listrik dalam kategori sedang. Keluarga contoh tergolong dalam keluarga kecil dengan jumlah anggota keluarga kurang dari empat orang $(55,8 \%)$. Rata-rata pendapatan keluarga contoh per kapita per bulan adalah Rp1.781.410,19. Tujuh dari sepuluh keluarga contoh memiliki pendapatan antara Rp212.210,00 sampai dengan Rp1.700.000,00 per kapita per bulan.

\section{Pesan Hemat Listrik}

Sembilan dari sepuluh contoh menganggap televisi sebagai sumber pesan 
yang memberi paling banyak informasi hemat listrik. Hasil penelitian juga menunjukkan bahwa sebanyak 54 persen contoh mempercayai informasi hemat listrik jika disampaikan oleh pemerintah. Selain itu, sebanyak 38 persen contoh mempercayai televisi sebagai media penyampai pesan hemat listrik. Berdasarkan jumlah sumber pesan, empat dari sepuluh contoh hanya mengakses informasi mengenai pesan hemat listrik dari satu sumber saja.

\section{Kesadaran}

Kesadaran merupakan tahap pertama dari perubahan kebiasaan penggunaan listrik dalam suatu pemasaran sosial. Tingkat kesadaran dibagi ke dalam tiga kelas, yaitu rendah, sedang, dan tinggi. Proporsi terbesar rumah tangga contoh berada pada tingkat kesadaran sedang, yaitu sebanyak 58,4 persen (Tabel 1 ).

\section{Perilaku Penggunaan Listrik Rumah Tangga}

Jumlah dan Waktu Penggunaan Alat Listrik. Alat listrik yang digunakan dalam jumlah paling banyak adalah lampu TL/neon. Jumlah kepemilikan lampu TL/neon rata-rata adalah 8,7 lampu per rumah tangga. Lama penggunaan rata-rata lampu TL/neon adalah 9,6 jam per hari. Masih terdapat contoh yang menggunakan bohlam, mulai dari hanya satu bohlam sampai dengan 14 bohlam. Rata-rata penggunaan bohlam pada rumah tangga contoh adalah 2,7 lampu per rumah tangga dengan rata-rata lama penggunaan bohlam 4,2 jam per hari.

Jumlah pemilikan alat listrik untuk pemanfaatan sekunder terbanyak adalah charger telepon seluler. Penggunaan charger telepon seluler adalah 311 dari 113 contoh, atau rata-rata 3,2 charger telepon selular per rumah tangga. Waktu penggunaan charger telepon selular rata-rata adalah 1,3 jam per hari. Jumlah pemilikan alat listrik untuk pemanfaatan sekunder terbanyak selanjutnya adalah televisi. Rumah tangga contoh rata-rata memiliki 1,6 televisi. Waktu penggunaan ratarata televisi rumah tangga contoh adalah 7,2 jam per hari.

Tabel 1 Sebaran rumah tangga contoh berdasarkan tingkat kesadaran

\begin{tabular}{lrrrrr}
\hline \multirow{2}{*}{ Kesadaran } & \multicolumn{5}{c}{ Daya Listrik (\%) } \\
\cline { 2 - 5 } & 900 & 1300 & 2200 & $>2200$ & Total \\
\hline Rendah & 13,0 & 12,5 & 0,0 & 0,0 & 8,8 \\
Sedang & 56,5 & 56,3 & 65,6 & 33,3 & 58,4 \\
Tinggi & 30,4 & 31,3 & 34,4 & 66,7 & 32,7 \\
\hline Total & 100,0 & 100,0 & 100,0 & 100,0 & 100,0 \\
\hline
\end{tabular}

Pemanfaatan primer listrik untuk penerangan yang terlama penggunaannya $(9,7$ jam) adalah pemanfaatan untuk lampu TL (lampu dalam rumah). Selain lampu TL, lampu taman atau lampu teras pun termasuk alat listrik yang digunakan dalam waktu yang lama (8,6 jam). Lampu TL biasa dinyalakan sejak sore hari sekitar pukul 17.00 WIB sampai dengan pagi hari keesokan harinya, namun ada pula yang mematikan lampu TL yang berada di dalam rumah ketika malam hari (saat tidur). Sedangkan lampu taman atau lampu teras ratarata mulai dinyalakan sekitar pukul 18.00 WIB sampai dengan pagi hari keesokan harinya.

Alat listrik yang digunakan untuk pemanfaatan primer pengudaraan yang paling lama penggunaannya (5,5 jam) adalah kipas angin. Contoh pada setiap golongan daya terpasang pada umumnya menggunakan AC selama 5,1 jam sampai dengan 5,8 jam setiap hari. Selain kipas angin, AC juga digunakan contoh dalam waktu yang cukup lama, yaitu rata-rata 4,3 jam per hari. Contoh pada daya terpasang 1300 VA yang memiliki AC rata-rata setiap harinya hanya menyalakan $A C$ selama 0,5 jam, sedangkan contoh pada daya terpasang $>2200$ VA rata-rata setiap harinya menyalakan AC selama 7,3 jam.

Tagihan Listrik. Rekening listrik rata-rata seluruh contoh selama bulan Januari 2010 sampai dengan Maret 2010 adalah Rp169.365,27 per bulan. Terdapat selisih antara penggunaan listrik dengan rata-rata penggunaan listrik nasional berdasarkan data PLN 2010 seperti terdapat pada Tabel 2. Rumah tangga contoh dengan daya terpasang 900 VA hampir seluruhnya $(95,7 \%)$ memiliki rekening listrik yang lebih tinggi dari rata-rata rekening listrik nasional untuk daya terpasang 900 VA. Hasil penelitian juga menunjukkan bahwa terdapat lebih dari separuh contoh pada setiap daya kecuali daya $>2200$ VA yang memiliki rekening listrik lebih besar dari ratarata rekening listrik untuk golongan masingmasing (Tabel 3).

Tabel 2 Perbandingan rekening listrik rata-rata contoh (rupiah/bulan) per golongan daya terpasang (VA) dengan rekening listrik rata-rata nasional (Rupiah/bulan)

\begin{tabular}{lcr}
\hline Daya & $\begin{array}{c}\text { Rekening listrik } \\
\text { rata-rata }\end{array}$ & $\begin{array}{c}\text { Rekening listrik } \\
\text { rata-rata nasional }\end{array}$ \\
\hline 900 & $96.668,43$ & $47.392,00$ \\
1300 & $144.429,19$ & $160.738,00$ \\
2200 & $269.800,59$ & $160.738,00$ \\
$>2200$ & $478.725,00$ & $492.090,00$ \\
\hline
\end{tabular}


Tabel 3 Perbandingan rekening listrik rata-rata nasional $(\mathrm{Rp})$ dengan rekening listrik pada setiap daya (VA)

\begin{tabular}{|c|c|c|c|c|c|}
\hline \multirow{2}{*}{$\begin{array}{l}\text { Rekening } \\
\text { listrik }\end{array}$} & \multicolumn{4}{|c|}{ Daya Listrik (\%) } & \multirow{2}{*}{ Total } \\
\hline & 900 & 1300 & 2200 & $>2200$ & \\
\hline$<47.392,00$ & 4,3 & 0,0 & 0,0 & 0,0 & 1,8 \\
\hline $\begin{array}{l}47.392,00- \\
160.738,00\end{array}$ & 93,5 & 68,8 & 18,8 & 0,0 & 62,8 \\
\hline $\begin{array}{l}160.739,00- \\
492.090,00\end{array}$ & 2,2 & 31,3 & 68,8 & 66,7 & 31,0 \\
\hline$>492.090,00$ & 0,0 & 0,0 & 12,5 & 33,3 & 4,4 \\
\hline Total & 100,0 & 100,0 & 100,0 & 100,0 & 100,0 \\
\hline
\end{tabular}

Pemanfaatan Primer dan Sekunder. Hasil penelitian menunjukkan bahwa sebanyak 86,7 persen rumah tangga contoh telah melakukan efektivitas penggunaan listrik (Tabel 4). Rumah tangga contoh dikatakan efektif menggunakan listrik karena memprioritaskan pemanfaatan primer listrik daripada pemanfaatan sekundernya. Akan tetapi belum tentu rumah tangga contoh hemat dalam menggunakan listrik. Sebaran rumah tangga contoh berdasarkan perbandingan pemanfaatan listrik primer dan sekunder disajikan pada Tabel 4.

Perilaku Hemat Listrik. Pada Tabel 5, proporsi terbesar rumah tangga contoh $(65,5 \%)$ termasuk dalam kelompok sedang perilaku hemat listrik. Hanya 3,5 persen saja rumah tangga contoh yang memiiliki perilaku hemat listrik kelompok tinggi. Masih terdapat 31,0 persen rumah tangga contoh yang termasuk dalam kelompok rendah perilaku hemat listrik. Lebih dari separuh contoh $(65,5 \%)$ memiliki perilaku hemat listrik kategori sedang. Hal ini berarti rumah tangga contoh telah mulai melaksanakan penghematan namun belum optimal pada seluruh barang elektronik yang dimiliki. Perilaku hemat listrik yang masih jarang dilakukan rumah tangga contoh adalah menghindari kebiasaan menggunakan magic jar untuk menghangatkan nasi.

Tabel 4 Sebaran rumah tangga contoh berdasarkan perbandingan pemanfaatan listrik primer sekunder dan daya (VA)

\begin{tabular}{|c|c|c|c|c|c|}
\hline \multirow{2}{*}{$\begin{array}{c}\text { Pemanfaat-an } \\
\text { listrik primer dan } \\
\text { sekunder }\end{array}$} & \multicolumn{4}{|c|}{ Daya Listrik (\%) } & \multirow{2}{*}{ Total } \\
\hline & 900 & 1300 & 2200 & $>2200$ & \\
\hline Efektif & 84,8 & 84,4 & 90,6 & 100,0 & 86,7 \\
\hline Belum efektif & 15,2 & 15,6 & 9,4 & 0,0 & 13,3 \\
\hline Total & 100,0 & 100,0 & 100,0 & 100,0 & 100,0 \\
\hline
\end{tabular}

Tabel 5 Sebaran rumah tangga contoh berdasarkan persentase perilaku kebiasaan hemat (\%) dan daya (VA)

\begin{tabular}{lrrrrr}
\hline \multirow{2}{*}{ Kategori } & \multicolumn{5}{c}{ Daya Listrik (\%) } \\
\cline { 2 - 5 } & 900 & 1300 & 2200 & $>2200$ & Total \\
\hline Rendah & 17,4 & 40,6 & 40,6 & 33,3 & 31,0 \\
Sedang & 78,3 & 56,3 & 56,3 & 66,7 & 65,5 \\
Tinggi & 4,3 & 3,1 & 3,1 & 0,0 & 3,5 \\
\hline Total & 100,0 & 100,0 & 100,0 & 100,0 & 100,0 \\
\hline
\end{tabular}

\section{Hubungan Antarvariabel Penelitian}

Analisis korelasi seperti yang tersaji pada Tabel 6 menunjukkan bahwa kesadaran berhubungan signifikan dengan pendidikan $(r=0,160, p<0,1)$ dan besar rumah tangga $(r=0,170, \quad p<0,1)$. Hasil penelitian juga menunjukkan bahwa, perilaku hemat listrik juga berhubungan signifikan dengan jumlah sumber pesan $(r=-0,190, p<0,05)$, jumlah pesan yang diingat contoh berdasarkan versi artis Lidya Kandou, besar rumah tangga $(r=0,187, p<0,05)$, pendapatan per kapita $(r=-0,331, p<0,01)$, daya $(r=-0,297, \quad p<0,01)$, dan rekening listrik $(r=-0,300, p<0,01)$.

Tabel 6 Koefisien korelasi antara jumlah sumber pesan, jumlah pesan yang diingat, kesadaran, dan karakteristik rumah tangga contoh dengan kesadaran dan perilaku hemat listrik

\begin{tabular}{lrr}
\hline \multicolumn{1}{c}{ Variabel } & Kesadaran & \multicolumn{1}{c}{$\begin{array}{c}\text { Perilaku } \\
\text { hemat listrik }\end{array}$} \\
\hline $\begin{array}{l}\text { Jumlah sumber pesan } \\
\text { Jumlah pesan yang } \\
\text { diingat contoh } \\
\text { berdasarkan versi }\end{array}$ & 0,058 & $-0,190^{\star *}$ \\
pesan & & \\
$\quad$ Lidya Kandou & $-0,056$ & $0,187^{* *}$ \\
$17.00-22.00$ & $-0,023$ & $-0,025$ \\
Maskot & $-0,149$ & 0,131 \\
$\quad$ Earth Hour & $-0,068$ & $-0,100$ \\
Kesadaran & 1,000 & $-0,051$ \\
Karakteristik rumah & & \\
tangga contoh & & \\
Umur & $-0,043$ & 0,031 \\
Pendidikan & $0,160^{*}$ & 0,010 \\
Besar rumah tangga & $0,170^{*}$ & $0,162^{*}$ \\
Pendapatan per & & \\
kapita & 0,076 & $-0,331^{* * *}$ \\
Daya & 0,131 & $-0,297^{\star * *}$ \\
Rekening listrik & 0,092 & $-0,300^{* * *}$ \\
Pengetahuan & 0,065 & 0,056 \\
\hline
\end{tabular}

Keterangan:

$\left({ }^{*}\right)$ signifikan pada $p<0,1$;

$\left.{ }^{* *}\right)$ signifikan pada $p<0,05$

$\left(^{* * *}\right)$ signifikan pada $p<0,01$ 


\section{PEMBAHASAN}

Kesadaran seorang konsumen dapat muncul dari karakteristik konsumen sendiri maupun dari stimulus eksternal. Pesan hemat listrik merupakan stimulus eksternal yang diterima oleh rumah tangga contoh. Penelitian ini menunjukkan bahwa pesan hemat listrik tidak berhubungan signifikan dengan kesadaran. Hasil ini menunjukkan bahwa kesadaran rumah tangga contoh untuk menghemat listrik tidak ditentukan oleh keterpaparan terhadap pesan hemat listrik. Hal ini dapat terjadi karena kesadaran rumah tangga contoh berhubungan dengan stimulus internal yang dimiliki rumah tangga contoh, misalnya karakteristik rumah tangga contoh.

Rumah tangga contoh memperoleh pesan hemat listrik tidak hanya dari satu sumber saja. Jumlah sumber pesan berhubungan negatif secara signifikan dengan perilaku hemat listrik rumah tangga contoh $(r=-0,190, p<0,05)$. Hal tersebut menunjukkan kuantitas informasi tidak membuat rumah tangga contoh semakin menghemat listrik. Semakin sedikit jumlah pesan yang diakses rumah tangga contoh, maka akan semakin tinggi perilaku hemat listrik yang dilakukan. Hal ini dapat terjadi karena semakin sedikit sumber informasi semakin rumah tangga contoh tidak bingung dengan pesan hemat listrik yang diperoleh. Informasi dari satu sumber sudah memenuhi kebutuhan rumah tangga contoh akan informasi hemat listrik.

Hasil penelitian menunjukkan adanya hubungan antara versi pesan dengan perilaku hemat listrik. Versi pesan pemasaran sosial berupa iklan yang dibintangi oleh artis Lidya Kandou memiliki hubungan positif yang signifikan dengan perilaku hemat listrik. Hal ini menunjukkan semakin seringnya rumah tangga contoh terpapar dengan pesan versi artis Lidya Kandou semakin tinggi perilaku hemat listrik yang dilakukan. Hal ini dapat terjadi karena isi pesan versi artis Lidya Kandou menunjukkan secara spesifik bagaimana saja cara menghemat listrik.

Hasil lain juga menunjukkan bahwa kesadaran tidak berhubungan dengan perilaku hemat listrik yang dilakukan rumah tangga contoh. Hal ini dapat terjadi karena hemat listrik bukan suatu hal yang baru bagi rumah tangga contoh. Solomon (2000) menyebutkan bahwa rumah tangga contoh diperkirakan telah berada pada fase konfirmasi (mengulang-ulang perilaku yang diinginkan dari suatu pemasaran sosial) sehingga tidak lagi berada pada fase kesadaran. Perilaku hemat listrik rumah tangga contoh berhubungan dengan faktor lain selain dari kesadaran.

Kesadaran merupakan tahap pertama sebelum rumah tangga contoh mengadopsi suatu kebiasaan baru. Kesadaran merupakan tahap ketika konsumen merasakan stimulus yang berasal dari suatu pemasaran sosial. Hasil penelitian menyebutkan bahwa beberapa karakteristik rumah tangga contoh yang berhubungan signifikan positif dengan kesadaran yaitu pendidikan anggota rumah tangga dan besar rumah tangga. Hal tersebut menunjukkan bahwa semakin tinggi pendidikan anggota rumah tangga dan semakin banyak jumlah anggota rumah tangga maka semakin tinggi juga kesadaran rumah tangga untuk menghemat listrik. Menurut Goldsmith (2005), terlepas dari tahapan yang sedang dijalani keluarga atau tipe keluarga, perbedaan utama antara pengambilan keputusan individu dengan pengambilan keputusan keluarga adalah keputusan akan lebih rumit jika melibatkan dua orang atau lebih. Semakin besar keluarga, semakin pelik proses pengambilan keputusan karena lebih banyak kebutuhan orang lain yang harus dipertimbangkan dan semakin banyak sumberdaya yang harus dipersiapkan.

Pengambilan keputusan keluarga adalah bagian yang penting dari banyak penelitian karena keluarga menurut Rettig dan Bubolz (1983), diacu dalam Goldsmith (2005) menyediakan tempat dan keadaan untuk membentuk, mengubah, mengalokasikan, dan bertukar sumberdaya untuk memenuhi kebutuhan fisik, keamanan, dan kebutuhan lain pada tingkat yang lebih tinggi dari seorang individu. Setiap karakteristik rumah tangga akan menghasilkan penggunaan listrik yang berbeda. Perbedaan karakteristik akan mengakibatkan perbedaan kebutuhan rumah tangga. Kebutuhan yang berbeda akan mengakibatkan kepemilikan aset yang berbeda, salah satunya yaitu alat-alat listrik. Kebiasaan penggunaan adalah kebiasaan rumah tangga rumah tangga contoh menggunakan alat-alat listrik yang dimiliki. Hasil penelitian menemukan adanya hubungan yang signifikan antara karakteristik rumah tangga contoh dengan perilaku hemat listrik yaitu besar rumah tangga, pendapatan per kapita, daya listrik, dan tagihan listrik.

Hubungan negatif signifikan antara pendapatan per kapita dengan perilaku hemat listrik menunjukkan bahwa perilaku hemat listrik hemat rumah tangga contoh tidak lepas dari pendapatan per kapita rumah tangga contoh. 
Semakin tinggi pendapatan per kapita rumah tangga contoh semakin rendah kebiasaan hemat listrik karena rumah tangga contoh mampu untuk membayar biaya penggunaan listrik yang semakin besar.

Hubungan negatif signifikan antara daya dengan perilaku hemat listrik menunjukkan bahwa semakin tinggi daya yang terpasang pada kediaman rumah tangga contoh maka semakin rendah perilaku hemat listrik hemat yang dilakukan oleh rumah tangga rumah tangga contoh. Hal ini disebabkan daya terpasang yang tinggi ditujukan untuk menyalakan alat listrik yang lebih banyak. Sementara itu, hubungan negatif signifikan antara tagihan listrik dengan perilaku hemat listrik menunjukkan bahwa rekening listrik merupakan gambaran dari perilaku hemat listrik hemat dalam rumah tangga rumah tangga contoh. Semakin boros perilaku hemat listrik anggota rumah tangga rumah tangga contoh dalam menggunakan alat listrik maka semakin tinggi rekening listrik.

Hubungan daya, tagihan listrik, dan pendapatan per kapita, dengan perilaku hemat listrik menunjukkan perilaku hemat listrik akan semakin rendah jika daya, rekening listrik, dan pendapatan per kapita semakin tinggi. Rendahnya perilaku hemat listrik sama artinya dengan tingginya penggunaan alat-alat listrik. Semakin besar daya dan pendapatan per kapita maka semakin tinggi kebiasaan penggunaan alat listrik (jumlah alat listrik semakin banyak dan lama pemakaian cenderung lebih lama). Kebiasaan penggunaan alat listrik yang tinggi akan berdampak pada tingginya rekening listrik.

Pendidikan dan pekerjaan rumah tangga contoh adalah dua karakteristik konsumen yang saling berhubungan. Pendidikan akan menentukan jenis pekerjaan yang dilakukan oleh seorang. Profesi dan pekerjaan seseorang akan mempengaruhi pendapatan yang diterimanya. Pendapatan dan pendidikan tersebut kemudian akan mempengaruhi proses keputusan dan pola konsumsi seseorang (Sumarwan, 2004). Jika pendapatan tinggi, maka aset yang dimiliki semakin banyak, dan rumah tangga contoh perlu memasang daya yang memadai untuk dapat menyalakan alatalat listrik.

\section{SIMPULAN DAN SARAN}

Hasil penelitian menunjukkan bahwa contoh mempercayai televisi sebagai media dan pemerintah sebagai kelompok acuan dalam menyampaikan pesan hemat listrik. Contoh memiliki kesadaran dan perilaku hemat listrik dalam kategori sedang. Berdasarkan indikator pemanfaatan listrik primer dan sekunder, sebagian besar contoh telah dapat melakukan efektivitas penggunaan listrik. Analisis korelasi menunjukkan bahwa kesadaran berhubungan signifikan dengan pendidikan dan besar rumah tangga. Hasil penelitian juga menunjukkan bahwa, perilaku hemat listrik juga berhubungan signifikan dengan jumlah sumber pesan, jumlah pesan yang diingat contoh berdasarkan versi pesan artis Lidya Kandou, besar rumah tangga, pendapatan per kapita, daya, dan rekening listrik.

Berdasarkan hasil, penelitian ini menyarankan agar pemasaran sosial dilakukan melalui media televisi. isi pesan yang disampaikan hendaknya berupa cerita atau gambaran penghematan listrik yang dapat dilakukan dalam kehidupan sehari-hari. Pemasaran sosial hemat listrik hendaknya dilakukan secara berkelanjutan baik oleh pihak PLN maupun swasta walaupun masyarakat telah melakukan penghematan.

\section{DAFTAR PUSTAKA}

Adywibowo, S. N. (2008). Berhemat Pasti Bermanfaat. Diambil dari http://www. plnjateng.co.id/?p=224. [diunduh 9 Maret 2010]

Bhaskoro, W. (2010). Listrik untuk Kehidupan. Diambil dari: http://wahyubhaskoro.com/ wp-content/uploads/2010/01/Listrik untuk Kehidupan - Alasan Mengapa Harus Berhemat Listrik serta 22 Tips Hemat Listrik.pdf. [diunduh 24 Februari 2010].

[BPS] Badan Pusat Statistik. (2010). Tingkat Kemiskinan Jawa Barat Maret 2010. Berita Resmi Statistik, 26/07/32/th.xii (1 Juli 2010).

Goldsmith, E. B. (2005). Resource Management for Individuals and Families. Belmont: Wadsworth.

Kuncoro, M. (2008). Habis BBM Terbitlah Krisis Listrik. [terhubung berkala]: http://www.seputar-indonesia.com/edisicetak/opini/habis-bbm-terbitlahlistrik3.html. [diunduh 21 Juli 2008].

Nuryanti, \& Herdinie, S. S. (2007). Analisis karakteristik konsumsi energi pada sektor rumah tangga di Indonesia. Seminar Nasional III SDM teknologi nuklir; 
Yogyakarta, 21-22 November 2007. Jakarta: BATAN.

Papalia, D. E., \& Old, S. W. (2006). Perkembangan Manusia Jilid 2 Edisi 10. Marswendy B, Penerjemah. Widyaningrum R, Editor. Jakarta: Salemba Humanika. Terjemahan dari Human Development $10^{\text {th }}$ Edition.
Solomon, M. R., et al. (2006). Marketing (International Edition). New Jersey: Pearson Education.

Sumarwan, U. (2004). Perilaku Konsumen. Jakarta: Ghalia Indonesia.

Susanta, G, \& Agustoni, S. (2007). Kiat Hemat Bayar Listrik. Jakarta: Penebar Swadaya. 